\title{
KEDUDUKAN JAKSA AGUNG PASCA PUTUSAN MAHKAMAH KONSTITUSI NOMOR 49/PUU-VIII/2010 DALAM PERSPEKTIF NEGARA HUKUM
}

\section{THE MAJESTIC PROSECUTOR POSITION POST-DECISION OF THE CONSTITUTIONAL COURT NUMBER 49 / PUU-VIII / 2010 IN LEGAL STATE PERSPECTIVE}

\author{
Ahadi Fajrin Prasetya \\ Fakultas Hukum Universitas Tulang Bawang Lampung \\ ahadifajrin147@gmail.com
}

\begin{abstract}
Abstrak
Penulisan ini bertujuan untuk mengetahui dasar pertimbangan pengambilan Putusan Mahkamah Konstitusi Nomor 49/PUU/VIII/2010 terhadap Pasal 22 Ayat (1) huruf d UndangUndang Nomor 16 Tahun 2004 dalam prinsip negara hukum dan mengetahui konsekuensi hukum tindakan hukum Jaksa Agung sebelum dan sesudah Putusan Mahkamah Konstitusi tersebut. Menggunakan metode penelitian yuridis normatif dengan analisis preskriptif. Kesimpulan penulisan ini bahwa pengambilan putusan Nomor 49 49/PUU-VIII/2010 berdasarkan ketentuan peraturan perundang-undangan yang berkaitan dengan Mahkamah Konstitusi, saksi-saksi serta para ahli yang dihadirkan oleh pemohon serta pemerintah. Konsekuensi hukum tindakan Jaksa Agung sebelum putusan Mahkamah Konstitusi terhadap pengeluaran kebijakan yang membawa akibat hukum terhadap pemohon dalam putusan Nomor 49/PUU-VIII/2010 adalah sah dan sesudah putusan Mahkamah Konstitusi, jabatan Jaksa Agung Hendarman Supanji dinyatakan tidak sah, namun putusan masih dapat dilakukan Rejudicial review apabila ada alasan konstitusional sebagaimana diatur dalam Peraturan Mahkamah Konstitusi Nomor 6 Tahun 2005 Tentang Tentang Pedoman Beracara Dalam Perkara Pengujian Undang-Undang.
\end{abstract}

Kata Kunci: Kedudukan Jaksa Agung, Putusan Mahkamah Konstitusi, Negara Hukum

\begin{abstract}
This writing aims to determine the basis for the consideration of the decision of the Constitutional Court Number 49/PUU-VIII /2010 on Article 22 Paragraph (1) letter d of Law Number 16 Year 2004 in the legal state prespective and to know the legal consequences of legal actions by the Attorney General before and after The Constitutional Court's decision. Using normative juridical research methods with prescriptive analysis. The conclusion of this writing is that the decision making number 49/PUU-VIII /2010 is based on the provisions of laws and regulations relating to the Constitutional Court, witnesses and experts presented by the petitioner and the government. The legal consequences of the Attorney General's actions prior to the Constitutional Court decision regarding the issuance of policies that brought
\end{abstract}


legal consequences to the applicant in decision Number 49/PUU-VIII/2010 were valid and after the Constitutional Court decision, the position of Attorney General Hendarman Supanji was declared invalid, but the verdict could still be made Rejudicial review if there are constitutional reasons as regulated in the Regulation of the Constitutional Court Number 6 of 2005 concerning Guidelines for Procedures in Judicial Review Cases.

Keywords : The Majestic Prosecutor Position, Decision Of The Constitusional Court, Legal State

\section{A. Pendahuluan}

Lahirnya Putusan Mahkamah Konstitusi (MK) Nomor 49/PUUVIII/2010 sebagai kelanjutan gugatan yang diajukan Yusril Ihza Mahendra sebagai Pemohon, merupakan akibat dari merebaknya kasus korupsi Sistem Administrasi Badan Hukum (Sisminbakum) berawal dari penolakan Pemohon dalam Putusan MK tersebut untuk diperiksa penyidik Kejaksaan Agung sebagai tersangka.

Yusril Ihza Mahendra menyebutkan bahwa kedudukan Jaksa Agung adalah illegal. Hal tersebut berdasarkan faktafakta, yaitu Keputusan Presiden (Keppres) Nomor 187 Tahun 2004, tentang Pembentukan Kabinet Indonesia Bersatu, Jaksa Agung dimasukkan menjadi anggota kabinet dengan kedudukan setingkat Menteri Negara. Keputusan Presiden ini ditertibkan pada tanggal 20 Oktober 2004. Tugas Kabinet Indonesia Bersatu (KIB), sesuai dengan masa jabatan Presiden adalah 5 (lima) tahun, dengan sendirinya tugas KIB berakhir tanggal 20 Oktober
2009. Jaksa Agung Hendarman Supanji, diangkat menjadi Jaksa Agung KIB berdasarkan Keppres Nomor 31/P Tahun 2007 tanggal 7 Mei 2007," dengan kedudukan setingkat Menteri Negara". Berdasarkan hal tersebut, maka tugas KIB sesuai dengan jabatan Presiden selama 5 tahun, dengan sendirinya berakhir pada tangggal 20 Oktober 2009. Dengan demikian, maka kedudukan Hendarman Supanji sebagai Jaksa Agung Republik Indonesia, yang menggantikan Abdul Rahman Saleh, berkahir pula dengan berakhirnya masa jabatan Presiden Republik Indonesia dan berakhir masa bakti KIB yang membantunya, yakni pada tanggal 20 Oktober 2009. Susilo Bambang Yudhoyono dan Boediono tanggal 20 Oktober 2009, telah dilantik oleh Majelis Permusyawaratan Rakyat sebagai Presiden dan Wakil Presiden Republik Indonesia.

Pada hari yang sama, Presiden telah membentuk KIB II untuk masa bakti 20092014. Dalam pemerintahan yang dipimpin oleh Presiden Susilo Bambang Yudhoyono dan Wakil Presiden Boediono, Hendarman 
Supanji tidak pernah diangkat kembali sebagai Jaksa Agung melalui Keputusan Presiden, baik menjadi anggota kabinet dengan status setingkat Menteri Negara, maupun Jaksa Agung sebagai pejabat negara, sebagaimana dimaksud dalam Pasal 19 Ayat (2) Undang-Undang Nomor 16 Tahun 2006 tentang Kejaksaan RI.

Berdasarkan hal tersebut, kedudukan Hendarman Supanji sebagai Jaksa Agung tidak memiliki landasan hukum, meskipun secara De Facto dia menjalankan tugas dan kewenangan seolah-olah seorang Jaksa Agung yang sah. Hendarman Supanji meskipun tidak memiliki landasan hukum atas jabatannya, menurut Yusril Ihza Mahendra telah bertindak seolah-olah Jaksa Agung yang sah, dan tekah melakukan tindakan-tindakan hukum dan/atau mengambil keputusan-keputusan serta membuat surat perintah jabatan, termasuk tidak terbatas pada mengusulkan kepada Presiden untuk mengangkat Jaksa Agung Muda Tindak Pidana Khusus (Jampidsus) M. Amari yang dilantik setelah tanggal 20 Oktober 2009 menggantikan Marwan Effendi.

Akibat pengusulan pengangkatan Jampidsus oleh Presiden tersebut, dilakukan oleh Jaksa Agung yang tidak memiliki landasan hukum, maka Keputusan Presiden yang mengangkat Jampidsus M. Amari itu mengandung cacat hukum bahwa adanya jabatan Jaksa Agung yang tidak memiliki landasan hukum dan dengan demikian tidak sah menurut hukum, yang telah menerbitkan keputusan-keputusan, penetapan, perintah jabatan dan kebijakan yang membawa akibat hukum yang dikeluarkan oleh Jaksa Agung yang telah berkahir masa jabatannya akibat kekeliruan menafsirkan dan menerapkan Pasal 22 Ayat (1) huruf d Undang-Undang Kejaksaan yang multi tafsir, telaha memberikan ketidakpastian hukum dan mencedarai jaminan perlindungan atas hukum yang adil terhadap diri Pemohon dalam Putusan MK Nomor 49/PUU-VIII/2010.

Menurut Philipus M. Hadjon ${ }^{1}$, mengenai legalitas kedudukan Jaksa Agung tersebut, dari sisi hukum maka isu legalitas Jaksa Agung adalah isu dalam ranah Ius Constitutum, sedangkan isu tentang masa jabatan Jaksa Agung, apabila cermati Undang-Undang Kejaksaan Agung maka isu tersebut masuk dalam ranah Ius Constituendum.

Pada ranah Ius Constitutum titik tolaknya adalah Undang-Undang Kejaksaan Pasal 19 Ayat (2) UndangUndang Nomor 16 Tahun 2004 tentang Kejaksaan menyatakan, Jaksa Agung

\footnotetext{
1 Putusan Mahkamah Konstitusi Nomor 49/PUU-VIII/2010, hIm.61.
} 
diangkat dan diberhentikan oleh Presiden. Pasal 22 Ayat (2) Undang-Undang Nomor 16 Tahun 2004 tentang Kejaksaan mempertegas, bahwa Jaksa Agung diberhentikan dengan Keputusan Presiden. Menurut Denny Indrayana, kalaupun ada jabatan seumur hidup bukan berarti bertentangan dengan prinsip-prinsip konstitusi. Alternatif Jabatan seumur hidup justru dapat sangat berkaitan dan sangat menguatkan prinsip indepedensi satu lembaga. Sepanjang Keppres Tahun 2007, yang terkait dengan Hendarman Supanji belum dicabut, maka dasar hukum Hendarman masih menggunakan Keppres tersebut.

Adanya perbedaan pendapat dalam proses persidangan perkara pada Putusan Nomor 49/PUU-VIII/2010, menyebabkan kebingungan penerapan prinsip negara hukum terhadap kepastian hukum hak-hak konstitusional pemohon dan memandang perlu untuk dilakukan penelitian terhadap putusan MK Nomor 49/PUU-VIII/2010 terhadap Kedudukan Jaksa Agung Pasca Putusan Dalam Perspektif Negara Hukum. Berdasarkan pada hal tersebut maka penulisan ini fokus pada dasar pengambilan Putusan Nomor 49/PUUVIII/2010 yang dilakukan Mahkamah Konstitusi terhadap Pasal 22 Ayat (1) huruf d Undang-Undang Nomor 16 Tahun 2004 dalam perspektif prinsip negara hukum dan konsekuensi atas tindakan hukum Jaksa Agung sebelum dan sesudah Putusan Mahkamah Konstitusi. Permasalahan tersebut akan dikaji menggunakan penelitian yuridis normatif dengan analisis preskriptif dan pendekatan studi kasus.

\section{B. Pembahasan}

\section{Duduk Perkara Dalam Putusan Mahkamah Konstitusi Nomor 49/PUU-VIII/2010}

Putusan Mahkamah Konstitusi Nomor 49/PUU-VIII/2010 adalah kelanjutan dari permohonan Yusril Ihza Mahendra sebagai pemohon, terkait dugaan kasus korupsi Sistem Adminisrasi Badan Hukum (Sisminbakum). Pemohon dalam perkara ini dipanggil oleh Kejaksaan Agung untuk dimintai keterangannya sebagai tersangka. Pemohon mendalilkan akibat penerapan Pasal 22 Ayat (1) huruf d Undang Undang Kejaksaan RI yang tidak sejalan dengan asas negara hukum dan memberikan perlindungan dan kepastian hukum, telah membuat Pemohon dirugikan hak-hak konstitusionalnya. Hak konstitusional Pemohon merupakan warga negara Indonesia yang dijamin konstitusi untuk mendapatkan pengakuan, jaminan, perlindungan, dan kepastian hukum yang adil dalam naungan negara hukum 
sebagaimana dimaksud Pasal 1 Ayat (3) dan Pasal 28 D Ayat (1) UUD 1945.

Pemohon menyebutkan bahwa kedudukan Jaksa Agung adalah illegal atau tidak sah. Hal tersebut berdasarkan faktafakta, yaitu Jaksa Agung Hendarman Supanji, telah diangkat menjadi Jaksa Agung "Kabinet Indonesia Bersatu" berdasarkan Keppres Nomor 31/P Tahun 2007 tanggal 7 Mei 2007, dengan kedudukan setingkat Menteri Negara", menggantikan Abdul Rahman Saleh yang diberhentikan dengan hormat dari jabatan nya. Keppres Nomor 31/P Tahun 2007, sebagaimana tercantum dalam konsideran menimbang huruf a, terkait dengan Keppres Nomor 187/M Tahun 2004 Tentang Pembentukan KIB, yang dibentuk tanggal 20 Oktober 2004. Namun dalam KIB II untuk masa bakti 2009-2014, dalam pemerintahan yang dipimpin Susilo Bambang Yudhoyono dan Wakil Presiden Boediono, Hendarman Supanji, tidak pernah diangkat kembali sebagai Jaksa setingkat Menteri negara, maupun sebagai Jaksa Agung sebagai pejabat negara, sebagaimana dimaksud dalam Pasal 19 Ayat (2) Undang-Undang Nomor 16 Tahun 2006 tentang Kejaksaan RI.

Akibat pengusulan pengangkatan Jampidsus oleh Presiden dilakukan oleh Jaksa Agung yang tidak memiliki landasan hukum, maka Keputusan Presiden yang mengangkat Jampidsus M. Amari itu mengandung cacat hukum. Adanya jabatan Jaksa Agung yang tidak memiliki landasan hukum, yang telah menerbitkan keputusankeputusan, penetapan, perintah jabatan, dan kebijakan yang membawa akibat hukum yang dikeluarkan oleh Jaksa Agung yang telah berkahir masa jabatannya akibat kekeliruan menafsirkan dan menerapkan Pasal 22 Ayat (1) huruf d Undang-Undang Kejaksaan yang multi-tafsir, telah memberikan ketidakpastian hukum dan mencederai jaminan perlindungan atas hukum yang adil terhadap diri Pemohon dalam Putusan Mahkamah Konstitusi Nomor 49/PUU-VIII/2010.

Pemohon meminta kepada Mahkamah Agung agar menerima permohonan Provisi Pemohon, yaitu untuk menerbitkan Putusan Sela yang memerintahkan Kejaksaan Agung RI untuk menghentikan, atau setidak-tidaknya menunda penyidikan perkara dugaan tindak pidana korupsi yang melibatkan Pemohon sebagai Tersangka dan mencabut, atau sekurang-kurangnya menunda pelaksanaan Surat Keputusan yang melarang Pemohon berpergian keluar negeri, menyatakan Pasal 22 Ayat (1) huruf d Undang-Undang Nomor 16 Tahun 2004 tentang Kejaksaan RI bertentangan dengan Pasal 1 Ayat (3) dan Pasal 28D Ayat (1) Presiden dan masa jabatan anggota kabinet, menyatakan Pasal 22 
Ayat (1) huruf d Undang-undang Nomor 16 Tahun 2004 tentang Kejaksaan RI, tidak mempunyai kekuatan hukum mengikat dengan segala akibat hukumnya, sepanjang tidak ditafsirkan sesuai masa jabatan Presiden dalam satu periode dan masa jabatan anggota kabinet.

\section{Dasar Pengambilan Putusan Mahkamah Konstitusi Nomor 49/PUU-VIII/2010}

MK dalam putusannya Nomor 49/PUU-VIII/2010 terhadap permohonan Yusril Ihza Mahendra sebagai Pemohon untuk memohon putusan Provisi agar Mahkamah Konstitusi untuk menghentikan atau sekurang-kurangnya menunda penyidikan berdasarkan Surat Perintah Penyidikan Direktur Penyidikan Jampidsus Nomor Print/F.2/Fd.1/06/2010 bertanggal 24 Juni 2010 dan Pemohon juga memohon putusan Provisi agar Mahkamah memerintahkan kepada Kejaksaan Agung RI untuk mencabut atau sekurangkurangnya menunda Surat Keputusan Jaksa Agung RI Nomor KEP212/D/Dsp.3/06/2010 tentang Pencegahan Dalam Perkara Pidana bertanggal 25 Juni 2010, ditolak oleh Mahkamah Konstitusi untuk dikabulkan dengan berbagai alasan pertimbangan, yaitu ${ }^{2}$ :

\footnotetext{
2 Ibid, hlm.124-125
}

a. Pertama, dalam Pengujian UndangUndang (Judicial Review), putusan Mahkamah hanya menguji norma abstrak, tidak mengadili putusan kasus konkret seperti penyidikan atau pencegahan dalam kasus pidana terhadap Pemohon oleh karena permohonan Pemohon masuk dalam kasus konkret maka Mahkamah tidak dapat mengabulkannya.

b. Kedua, sejalan dengan alasan yang pertama maka Mahkamah harus menolak putusan Provisi tentang penyidikan dan pencegahan yang dilakukan oleh institusi Kejaksaan karena putusan Mahkamah tentang norma dalam kasus Pengujian UndangUndang (Judicial Review) bersifat Erga Omnes. Artinya, berlaku umum dan mengikat untuk semua kasus di seluruh Indonesia. Oleh sebab itu, Mahkamah tidak dapat memutus perkara konkret yang tertuju hanya terhadap satu kasus seperti dalam permohonan pada Putusan Nomor 49/PUU-VIII/2010 karena jika dilakukan berarti bertentangan dengan sifat Orge Omnes tersebut.

c. Ketiga, fungsi Kejaksaan sebagai intitusi tidak selalu bergantung pada fungsi Jaksa Agung sebagai pejabat, sehingga seumpama pun jabatan Jaksa Agung tidak sah, quad non, maka tidak 
dengan sendirinya penyidikan dan pencegahan oleh institusi Kejaksaan menjadi tidak sah sebab tugas penyidikan adalah tugas fungsional Kejaksaan yang bersifat permanen. Lebih dari itu, diluar masalah keabsahan Jaksa Agung, dalam kasuskasus tertentu, ada indikasi ketidak absahan atau ilegalitas dalam penyidikan maka forum hukumnya berada diluar kompetensi Mahkamah;

d. Keempat, putusan Mahkamah bersifat prospektif sesuai dengan ketentuan Pasal 58 Undang-Undang MK serta Pasal 38 dan Pasal 39 PMK Nomor 06/PMK/2005, tentang Pedoman Beracara Dalam Perkara Pengujian Undang-Undang, sehingga agar pun amar Putusan Nomor 49/PUUVIII/2010 tidak berlaku surut terhadap perkara konkret yang sudah atau sedang berlangsung.

Berdasarkan alasan-alasan tersebut, MK menegaskan kembali bahwa pertimbangan terhadap pokok permohonan yang diajukan oleh Pemohon di tolak, yang pada dasarnya menguji konstitusionalisme Pasal 22 Ayat (1) huruf d Undang-Undang Nomor 16 Tahun 2004 tentang Kejaksaan RI yang menyatakan "Jaksa Agung diberhentikan dengan hormat dari jabatannya karena berakhirnya masa jabatannya."

MK berpendapat, pemahaman yang berkaitan dengan makna frasa "Diberhentikan dengan hormat jabatannya" dan frasa " berakhir masa jabatannya" dalam hubungan nya dengan fungsi, tugas, dan wewenang dari suatu jabatan adalah sebagai berikut ${ }^{3}$ :

1. Frasa "diberhentikan dengan hormat dari jabatannya" dapat dimaknai dengan diberhetikan seorang pejabat dari segala fungsi dan wewenang yang telah diamanatkan dan dibebankan kepadanya, karena dia telah melaksanakan fungsi dan wewenang tersebut, dan dianggap bahwa segala sesuatu yang diamanatkan telah dilaksanakan dengan baik dan paripurna. Dalam hal ini, fokusnya adalah pada jenis jabatan tersebut yaitu pada fungsi dan wewenang yang diemban oleh pejabat yang bersangkutan, namun demikian jenis jabatan tersebut tetap ada dan perlu ditindak lanjuti, sehingga jabatan tersebut harus dilanjutkan oleh sesorang yang akan dipilih atau diangkat untuk menggantikannya. Dalam kaitannya dengan sifat

\footnotetext{
${ }^{3}$ Ibid.HIm. 126
} 
wewenang pemerintahan terdapat tiga ciri, yaitu:

a. Selalu terikat pada suatu masa tertentu;

b. Selalu tunduk pada batas yang ditentukan;

c. Pelaksanaan wewenang terikat pada hukum tertulis dan hukum tidak tertulis.

2. Sifat wewenang pertama, yaitu "selalu terikat pada suatu masa tertentu." Mempunyai makna bahwa lamanya wewenang tersebut ditentukan dalam peraturan yang menjadi dasar pemberiannya, yang biasa disebut lingkup waktu (Tijdsgebied). Sifat wewenang kedua yaitu "selalu tunduk pada yang ditentukan" yang berarti terdapat batas yang ditentukan, baik yang mencakup batas kewenangan wilayah (Plaatsgebeid) maupun batas cakupan materi kewenangan (Ruimtegebeid).

3. Frasa "berakhir masa jabatan" selalu dikaitkan dengan saat atau waktu tertentu yang biasanya telah ditentukan sebelumnya dalam suatu peraturan yang dibentuk untuk pelaksanaan dari jabatan tersebut, sehingga masa jabatan dari pemegang jabatan seharusnya diatur secara tegas untuk menghindarkan adanya pelampauan kewenangan.
Dalam proses persidangan, dasar pengambilan Putusan MK didasari pada bukti-bukti tertulis, keterangan para ahli, saksi-saksi dan pemerintah. Pada kesempatan yang diberikan pada Pemohon, mengajukan bukti berupa keterangan ahli untuk mengatakan dalildalilnya sebagai berikut ${ }^{4}$ :

1. Bagir Manan, menerangkan maksud dari klausus "berakhir masa jabatannya" pada Pasal 22 huruf d Undang-Undang Nomor 16 tentang Kejaksaan RI adalah:

a. Ada masa jabatan Jaksa Agung;

b. Masa jabatan Jaksa Agung terbatas, bukan satu jabatan yang tidak terbatas;

c. Sesuai dengan prinsip negara hukum mengenai jabatan,tidak boleh masa jabatan didasarkan diskresi seseorang.

Masa jabatan Jaksa Agung bukan jabatan seumur hidup, maka jabatan itu akan berakhir pada waktu tertentu.

2. Laica Marzuki, menerangkan fungsi Kejaksaan dibawah Jaksa Agung, dalam kaitan kekuasaan kehakiman, merupakan fungsi kekuasaan yang dilaksanakan secara merdeka, sebagaimana kekuasaan mereka yang melekat pada kekuasaan kehakiman

${ }^{4}$ Ibid.HIm.37-47. 
menurut Pasal 24 Ayat (1) UUD 1945. Pasal 2 Ayat (2) Undang-Undang Nomor 16 Tahun 2004 menetapkan, bahwa Kejaksaan dibawah Jaksa Agung, selaku lembaga pemerintahan yang melaksanakan kekuasaan negara di bidang penuntutan serta kewenangan lainnya dilaksanakan secara merdeka. Penjelasan Pasal 2 Ayat (1) Undang-Undang Nomor 16 Tahun 2004, menyatakan yang dimaksud "Merdeka" dalam ketentuan ini adalah melaksanakan fungsi, tugas, dan wewenangnya terlepas dari pengaruh kekuasaan pemerintah dan pengaruh kekuasaan lainnya. Demikian penting jabatan Jaksa Agung selaku pimpinan dan penanggung jawab tertinggi Kejaksaan yang memimpin serta mengendalikan pelaksanaan tugas dan wewenang Kejaksaan maka jabatan publik yang diemban Jaksa Agung harus sah dan tidak boleh bercacat hukum (Juridische gebreken). Jabatan Jaksa Agung, menurut Pasal 19 Undang-Undang Nomor 16 Tahun 2004 tentang Kejaksaan RI, adalah pejabat negara, diangkat dan diberhentikan oleh Presiden. Pasal 22 Ayat (1) Undang-undang Nomor 16 Tahun 2004 tentang Kejaksan RI, menetapkan Jaksa Agung diberhentikan dengan hormat dari jabatannya karena: a. Meninggal dunia; b. Permintaan sendiri; c. Sakit Jasmani atau Rohani terus - menerus; d. Berakhir masa jabatannya; e. Tidak lagi memenuhi syarat sebagaimana dimaksud dalam Pasal 21 UndangUndang Nomor 16 Tahun 2004 tentang Kejaksaan RI. Tidak demikian halnya dengan Jaksa Agung Hendarman Supanji yang masa jabatannya tak kunjung berakhir. Berdasarkan Keputusan Presiden (Keppres) Nomor 187 Tahun 2004 tentang Pembentukan KIB, Jaksa Agung dimasukan menjadi anggota kabinet dengan kedudukan setingkat menteri negara. Keputusan Presiden bertanggal 20 Oktober 2004. Tugas KIB, sesuai masa jabatan Presiden adalah 5 (lima) tahun. Maka dengan sendirinya tugas kabinet berakhir pada tanggal 20 Oktober 2009. Sudah saatnya MK mengakhiri multitafsir (Polyinterpretabel) Pasal 22 Ayat (1) huruf d Undang-Undang Nomor 16 Tahun 2004 tentang Kejaksaan RI, bahwa frasa "Berakhirnya masa jabatan "Jaksa Agung adalah bersamaan dengan berakhirnya masa bakti suatu kabinet, yang didalamnya termasuk Jaksa Agung selaku anggota 
kabinet, berkedudukan setingkat Menteri negara.

3. H.A.S Natabaya, menerangkan ada beberapa cara kehilangan jabatan yang disebut dengan $\mathrm{ambt}^{5}$ verlies. Hukum positif atau hukum tata negara positif mengatur kaidah-kaidah cara berakhirnya satu jabatan, antara lain berhenti atau Bedankt, pemberhentian atau Ontslag atau berakhirnya masa jabatan Aflopen van de ambtstermijn. Masalah dalam permohonan pada putusan Nomor 49/PUU-VIII/2010 adalah berakhirnya masa jabatan, ada Aflopen van de ambtstermijn. Dalam Pasal 19 Undang-Undang Nomor 16 Tahun 2004 tentang Kejaksaan RI menentukan, "Jaksa Agung adalah pejabat negara, Jaksa Agung diangkat dan diberhentikan Presiden”. Berarti, perolehan jabatan adalah dengan pengangkatan atau penunjukan oleh Presiden dan mengenai Aflopen diatur dalam Pasal 22 Undang-Undang Nomor 16 Tahun 2004 yang menyatakan, "Jaksa Agung diberhentikan dengan hormat dari jabatan karena:

a. Meninggal dunia;

${ }^{5}$ Ambt adalah pribadi, tetapi dia tidak bisa melakukan perbuatan tanpa ada orang yang mewakilinnya. Hal tersebut disebut dengan Amtsdrager atau pemangku jabatan. b. Permintaan sndiri;

c. Sakit jasmani dan rohani terus menerus;

d. Berakhir masa jabatannya.

Tidak ada masa jabatan yang diatur Undang-Undang Nomor 16 Tahun 2004 tentang Kejaksaan Agung RI. Menurut Beginselen van behoorlijke regelgeving (asas-asas pembentukan perundangundangan yang baik) yang diambil oleh Pasal 6 Undang-Undang Nomor 12 Tahun 2011, setiap Undang-Undang itu harus mempunyai beberapa asas, antara lain mengenai :

1. Asas mengenai kejelasan tujuan;

2. Kelembagaan atau pejabat pembentuk yang tepat;

3. Kesesuaian antara jenis, hierarki dan materi muatan;

4. Dapat dilaksanakan;

5. Kedayagunaan dan kehasilgunaan;

6. Kejelasan rumusan;dan

7. Keterbukaan.

Sejalan dengan hal tersebut, dalam pemerintahan yang baik juga harus memakai asas-asas mengenai pemerintahan yang baik Algemene beginselen van behoorlijke bestuur. Dalam rangka good governance harus juga asasasas diterapkan dan kepastian hukum Rechtszekerheid, Legal certainty dan hal 
tersebut ditentukan dalam Pasal 28 UUD 1945.

Pemohon juga mengajukan saksi Erman Rajagukguk ${ }^{6}$ yang menerangkan bahwa Jaksa Agung Republik Indonesia selalau diangkat Presiden diawal pembentukan kabinet dan jabatan itu berakhir bersamaan dengan berakhirnya masa kabinet yang disesuaikan dengan masa jabatan Presiden dan Wakil Presiden selama 5 (lima) tahun.

Selain keterangan para ahli dan saksi yang diajukan Pemohon, MK juga menerima keterangan tertulis yang disampaikan dari pemerintah. pemerintah ${ }^{7}$ pada dasarnya menghargai upaya hukum yang dilakukan Pemohon, termasuk mengajukan permohonan Pengujian Undang-Undang pada Putusan Nomor 49/PUU-VIII/2010, agar proses penegakan hukum dapat berjalan secara egaliter, profesional, transparan, akuntabel, dan menjunjung tinggi prinsip-prinisp negara hukum berkeadilan.

Menurut Pemerintah ${ }^{8}$ terdapat kerancuan (Missleading) dalam mengkontruksikan anggapan adanya kerugian konstitusional yang dimaksud Oleh Pemohon, karena sebagaimana telah

\footnotetext{
${ }^{6}$ Ibid. HIm. 47-48

${ }^{7}$ Ibid.hlm. 49

${ }^{8}$ Ibid, hlm.52
}

disinggung diatas, menurut Pemerintah kerugian yang dialami Pemohon, adalah berkaitan dengan berlakunya UndangUndang Nomor 31 Tahun 1999 sebagaimana telah diubah dengan UndangUndang Nomor 20 Tahun 2001 tentang Pemberantasan Tindak Pidana Korupsi, dengan perkataan lain menurut Pemerintah berkaitan dengan norma/implementasi maupun dalam rangka proses penegakan hukum atas dugaan telah terjadinya tindak pidana korupsi yang diantara lain melibatkan Pemohon, yang pelaksanaanya/penerapannya mengacu pada Kitab Undang-Undang Hukum Acara Pidana (KUHAP).

Berdasarkan hal tersebut, menurut Pemerintah permasalahan yang terjadi terhadap Pemohon adalah tidak terkait dengan masalah konstitusionalitas keberlakuan materi muatan norma Undang-Undang pada Putusan Nomor 49/PUU-VIII/2010 yang dimohonkan diuji tersebut, akan tetapi berkaitan dengan penerapan/implementasi norma UndangUndang pada Putusan Nomor 49/PUUVIII/2010.

Ketentuan yang dimohonkan untuk diuji adalah berkaitan dengan pengangkatan dan pemberhentian Jaksa Agung merupakan ranah tindakan administratif, sehingga menurut pemerintah, fakta hukum yang demikian 
tidak berkaitan dengan masalah konstitusionalitas keberlakuan materi muatan norma Undang-Undang pada Putusan Nomor 49/PUU-VIII/2010 yang dimohonkan untuk diuji oleh Pemohon.

\section{Amar Putusan Mahkamah Konstitusi}

MK memberikan putusan setelah proses persidangan berlangsung yang melibatkan alat bukti yang disampaikan, keterangan ahli, keterangan para saksi dan pemerintah. Proses persidangan berlangsung dengan perdebatan diantara pemohon, para saksi, para ahli yang dihadirkan, termasuk perdebatan diantara hakim konstitusi sendiri.

Amar putusan MK pada perkara ini menyatakan bahwa MK mengabulkan permohonan Pemohon untuk sebagian. MK menyatakan Pasal 22 Ayat (1) huruf d Undang-Undang Nomor 16 Tahun 2004 tentang Kejaksaan Agung RI sesuai dengan UUD 1945 secara bersyarat (Conditionally constitusional) ${ }^{9}, \quad$ yaitu konstitusional sepanjang dimaknai:

"Masa jabatan Jaksa Agung itu berakhir dengan berakhirnya masa jabatan Presiden RI dalam satu periode bersamasama masa jabatan anggota kabinet atau diberhentikan dalam masa jabatan oleh Presiden dalam periode yang bersangkutan".

\footnotetext{
9 Ibid hlm, 134.
}

Pengertian konstitusionalitas bersyarat dalam putusan MK adalah putusan yang menyatakan bahwa suatu ketentuan Undang-Undang tidak bertentangan dengan konstitusi sepanjang dengan pelaksanaanya (baik oleh eksekutif, legilatif maupun yudikatif) ditafsirkan sesuai dengan persyartan konstitusional yang ditentukan oleh $\mathrm{MK}^{10}$. Apabila syarat tersebut tidak dipenuhi atau ditafsirkan lain oleh lembaga negara yang melaksanakannya, maka ketentuan Undang-Undang yang telah diuji tersebut dapat diajukan dan diuji kembali oleh MK (rejudicial review).

Permohonan putusan provisi yang diminta oleh Pemohon tentang ketidakabsahan tindakan dan kebijakan Jaksa Agung Hendarman Supanji yang harus disertai dengan penghentian penyidikan dan pencegahan dalam tindak pidana terhadap Pemohon, menurut pertimbangan MK tidak tepat menurut Pemohon, menurut pertimbangan MK tidak tepat menurut hukum karena tidak terkait langsung dengan pokok permasalahan pada Putusan Nomor 49/PUU-VIII/2010, dengan beberapa alasan yaitu bahwa dalam Pengujian

\footnotetext{
${ }^{10} \mathrm{http}: / /$ yancearizona.files.wordpress.com/200 8/11/di-balik-konstitusionalitas-bersyaratpitusan-MK final.pdf, diakses tanggal 1 februari 201 pukul 15.20 WIB
} 
Undang-Undang, putusan MK hanya menguji norma abstrak, penghentian penyidikan adalah kasus konkret yang bukan kewenangan ranah kewenangan MK. Selain itu juga, MK merasa harus menolak putusan provisi mengenai penghentian penyidikan tersebut karena putusan MK tentang norma dalam kasus Pengujian Undang-Undang bersifat erga omnes, yang berarti putusan tersebut berlaku umum dan mengikat untuk semua kasus di Indonesia.

\section{Putusan Mahkamah Konstitusi Dalam Persspektif Prinsip Negara Hukum}

Permasalahan kedudukan Jaksa Agung di dalam gugatan yang diajukan Yusril Ihza Mahendra dan diputus pada Putusan MK Nomor 49/PUU-VIII/2010 pada pokoknya mempersoalkan kewenangan Jaksa Agung Hendarman Supanji terhadap penetapan dirinya sebagai tersangka dan penghentian hakhaknya sebagai warganegara, bersumber ketidak-jelasan legalitas penerapan Pasal 22 Ayat (1) huruf d Undang-Undang Kejaksaan yang multitafsir. Akibat penerapan Pasal 22 Ayat (1) UndangUndang Kejaksaan yang tidak sejalan dengan asas-asas negara hukum dan memberikan perlindungan dan kepastian hukum, telah memberikan kerugian hakhak konstitusional kepada Yusril Ihza
Mahendra sebagai pemohon dalam perkara tersebut.

Dasar pengambilan Putusan MK Nomor 49/PUU-VIII/2010 didasarkan pada keterangan ahli, keterangan saksi, keterangan pemerintah, bukti-bukti, serta pertimbanagan para hakim MK untuk memutus yang berdasarkan asas-asas yang berlaku dalam putusannya, mengacu pada prinsip kepastian hukum sebagaimana yang diuraikan Scheltema ${ }^{11}$, bahwa tolak ukur pencapaian kepastian hukum dalam suatu negara hukum sudah mengandung;

a. Asas legalitas, konstitusionalitas, dan supremasi hukum;

b. Asas Undang-Undang menetapkan berbagai perangkat peraturan tentang cara pemerintah dan para pejabatnya melakukan tindakan pemerintahan;

c. Asas non-reaktif perundang-undangan sebelum mengikat Undang-Undang harus lebih dahulu diundangkan dan diumumkan secara layak;

d. Asas peradilan bebas, independent, imparial dan objektif, rasional, adil, dan manusiawi;

e. Asas non-liquet, hakim tidak boleh menolak perkara karena alasan

11 B. Arief Sidharta, Kajian Kefilsafatan Tentang Negara Hukum, Jurnal Hukum Jentera, Edisi 3 tahun II November, 2014, hlm.124-125 
Undang-Undang tidak ada atau tidak jelas;

f. Hak asasi manusia dirumuskan dan dijamin perlindungannya dalam Undang-Undang atau UUD.

Berdasarkan hal tersebut, MK dalam putusannya sependapat bahwa kedudukan Jaksa Agung Hendarman Supanji bertentangan dengan asas legalitas yang merupakan kesatuan dari penegakan primsip negara hukum karena kedudukan Jaksa Agung Hendarman Supanji membawa ketidakpastian dari lama jabatan seorang Jaksa Agung. Seperti yang diuraikan pendapat ahli Bagir Manan dalam keterangan nya pada Putusan MK Nomor 49/PUU-VII/2010 adalah tidak benar suatu jabatan tidak memiliki batas akhir jabatan dan hal tersebut bertentangan dengan kepastian hukum dalam prisip negara hukum.

Asas non reaktif, Putusan MK bersifat prospektif sesuai dengan ketentuan Pasal 58 Undang-Undang MK serta Pasal 38 dan Pasal 39 Peraturan MK Nomor 06/PMK/2005 tentang Pedoman Beracara Dalam Perkara Pengujian UndangUndang, sehingga apapaun putusan amar Mahkamah dalam Putusan Nomor 49/PUU-VII/2010 tidak berlaku surut terhadap konkret yang sudah atau sedang berlangsung.
Penerapan dari asas non reaktif tersebut tidak terlepas dari tujuan penegakan negara hukum di Indonesia yang berlandaskan prinsip disuatu negara hukum harus menjunjung tinggi kepastian hukum. Kepastian hukum menyangkut hak-hak asasi maupun hak-hak konstitusional seseorang yang apabila suatu peraturan perundang-undangan maupun putusan pengadilan tidak berlaku asas non-retroaktif, dapat menciderai hakhak tersebut. Sesuai dengan pendapat Sudikno Metokusumo ${ }^{12}$, yang menyatakan tanpa kepastian hukum orang tidak tahu apa yang harus diperbuatnya dan akhir timbul keresahan. Tetapi lebih menitikberatkan kepada kepastian hukum, terlalu ketat mentaati peraturan hukum akibatnya kaku dan akan menimbulkan rasa tidak adil.

Prinsip kepastian hukum dalam konsep negara hukum Pancasila selalu terkait dengan prinsip keadilan yang bebas. Menurut Ismail Suny ${ }^{13}$, prinsip peradilan bebas biasanya dikaitkan pula

\footnotetext{
12 Sudikno Mertokusumo, Mengenal Hukum (Suatu Pengantar), (Yogyakarta: Liberty, 1998), hIm.136.

13 Ismail Suny dalam Muhammad Tahir Azhary, Negara Hukum, Negara Hukum: Suatu studi tentang Prinsip-Prinsipnya dilihat dari segi hukum Islam, Implementasinya pada Periode Negara Madinah dan Masa Kini, (Jakarta: Prenada Media, 2004), hIm 212-214.
} 
dengan pemisahan kekuasaan. Hubungannya dengan negara hukum dan trias politica $^{14}$ ( pemisahan kekuasaan), Ismail Suny menyebutkan, bahwa dalam suatu negara yang penting bukan ada atau tidaknya trias poltica tersebut, persoalan nya adalah dapat atau tidak alat-alat kekuasaan negara itu dihindarkan dari praktek birokrasi dan tirani.

Sesuai dengan pendapat Jimly Assiddiqie $^{15}$, negara hukum salah satu cirinya adalah asas peradilan yang bebas dan tidak memihak. Lebih lanjut dikatakan mengenai ciri tersebut dalam menjalankan tugas judisial nya, hakim tidak boleh dipengaruhi oleh siapapun juga, baik dari kepentingan jabatan (politik) maupun kepentingan uang (ekonomi). Untuk menjamin keadilan dan kebenaran, tidak diperkenakan adanya intervensi kedalam proses pengambilan putusan keadilan oleh hakim, baik intervensi dari lingkungan kekuasaan eksekutif maupun legislatif

\footnotetext{
${ }^{14}$ Bandingkan dengan pendapat Ismail Suny yang menyimpulkan pada umumnya pemisahan kekuasaan dalam arti materiil tidak terdapat dan tidak pernah dilaksanakan di Indonesia, yang ada dan dilaksanakan pemisahan kekuasaan dalam arti formil, atau dengan kata lain di Indonesia terdapat pembagian kekuasaan dengan tidak menekankan pada pemisahannya bukan pemisahan kekuasaan.

15 Jimly Assiddiqie, Menuju Negara Hukum Yang Demokratis, (Jakarta: Bhuana IImu Populer, 2009), hlm.203.
}

ataupun dari kalangan masyarakat dan media masa.

\section{Kesimpulan}

Setelah menjawab permasalahan dan pokok bahasan pada bab sebelumnya, maka dapat ditarik kesimpulan yaitu Dasar pengambilan Putusan MK Nomor 49/PUU-VIII/2010 oleh hakim MK diambil berdasarkan pertimbangan keterangan saksi ahli, keterangan saksisaksi, keterangan pemerintah, dan buktibukti yang didasari pada prinsip negara hukum mengenai kepastian hukum dan peradilan bebas yang tidak memihak dan serta konsekuensi hukum tindakan hukum Jaksa Agung sebelum Putusan MK tetap sah dah berlaku sesuai dengan sifat putusan MK. Konsekuensi tindakan hukum Jaksa Agung Hendarman Supanji setelah putusan MK dinyatakan tidak dapat berlaku lagi dan Jaksa Agung Hendarman Supanji dinyatakan tidak sah.

\section{Daftar Pustaka}

\section{Buku}

Jimly Asshiddiqie, Menuju Negara Hukum Yang Demokratis. Jakarta : Bhuana Ilmu Populer, 2009.

Sudikmo Mertokusumo, Mengenal Hukum (Suatu Pengantar), Yogyakarta: Liberty, 1998. 
Muhammad Tahir Azhary, Negara diakses tanggal 1 Oktober 2020 Hukum: Suatu studi tentang pukul 15.20 WIB

Prinsip-Prinsipnya dilihat dari segi hukum Islam, Implementasinya pada Periode Negara Madinah dan Masa Kini. Jakarta: Prenada Media, 2004.

\section{Karya Ilmiah}

B. Arief Sidharta, Kajian Kefilsafatan Tentang Negara Hukum, Jurnal Hukum Jentera, Edisi 3 tahun II November, 2014

\section{Peraturan Perundang-Undangan}

Undang-Undang Dasar Negara Republik Indonesia Tahun 1945

Undang-Undang Nomor 16 Tahun 2004 Tentang Kejaksaan Republik Indonesia.

Undang-Undang Nomor 12 Tahun 2011 tentang Pembentukan Peraturan Perundang-Undangan.

\section{Putusan Mahkamah Konstitusi}

Peraturan Mahkamah Konstitusi Republik Indonesia Nomor 06/PMK/2005 tentang Pedoman Beracara dalam Perkara Pengujian Undang-Undang

Putusan Mahkamah Konstitusi Nomor 49/PUU-VIII/2010 tentang Pengujian Terhadap Pasal 22 Ayat (1) huruf d Undang-Undang Nomor 16 Tahun 2004 tentang Kejaksaan Republik Indonesia.

\section{$\underline{\text { Website }}$}

http://yancearizona.files.wordpress.com/20 08/11/di-balik-konstitusionalitasbersyarat-putusan-mk_files.pdf. 